\title{
The atmospheric composition changes above the West Kunlun Mountain, Qinghai-Tibetan Plateau
}

\author{
E Chong Yi ${ }^{1,2, a^{*}}$ Sun YongJuan ${ }^{2, b}$ Li YongGuo ${ }^{3,4, c}$ Ma XingHua ${ }^{3,4, d}$
}

1 Key Laboratory of Qinghai-Tibetan Plateau Environment and Resource, MOE, Qinghai Normal University, 810000 Xining, China

2 Qinghai Institute of Salt Lakes, Chinese Academy of Sciences, 810000 Xining, China

3 Hydrogeology And Engineering Geology Environmental Geology Prospecting Institute of Qinghai Province, 810008, Xining, China

4 Hydrogeology And Geothermal Geology Key Laboratory of Qinghai Province, 810008, Xining, China

a echongyi@163.com , byjsun@isl.ac.cn, ${ }^{c}$ 876333320@qq.com, ${ }^{d}$ 462967182@qq.com

Keywords: atmospheric environmental change, Chongce ice core, ion sources.

Abstract. Chongce ice core, drilled from West Kunlun Mountain, 6350 meters high, provides a unique opportunity to obtain the past atmospheric environmental information. In this paper, the composition and concentration of ions, ions sources in Chongce ice core were analyzed, and the ions variation during last century were reconstructed. Results show that (1) Calcium ion shows the greatest proportion of ions concentration. (2) The major ions are mainly originated from Taklimkan Desert through sandstorm transport and wet deposition process. (3) The major mineral dust ions $\mathrm{Ca}^{2+}, \mathrm{SO}_{4}{ }^{2-}$, $\mathrm{Cl}^{-}, \mathrm{Na}^{+}$and $\mathrm{Mg}^{2+}$ show a decreased trend during the last century, in according with the decreased sandstorm frequency occurring in Taklimkan Desert. (4)The potassium ions show an increased trend during last century, especially after 1950, this related with the increased biomass burning. (5)The nitrite ions show a relatively stable variation during the last century, and there is a remarkable 11-17year period

\section{Introduction}

Ice core provides a unique opportunity to obtain the past climatic and environmental information. The detailed information includes: $\delta^{18} \mathrm{O}$, accumulation rate, water-soluble ions, insoluble particles, $\mathrm{pH}$, electric conductivity and so on. Water-soluble ions provide a lot of information on past atmospheric composition, with both short events (volcanic eruptions, storms, forest fires) and long-term changes (anthropogenic input, biogenic production, temperature variations) recorded. Qinghai-Tibetan Plateau (QTP) is one of the most sensitive areas to respond to global climate change. The ice cores retrieved from the QTP are spanning from decades to hundreds thousands. The study of ion chemistry records in such a significant region presents a different type of climate information and environment change. The variation of ion concentrations have been used to study monsoon and dust signals, emissions from fossil fuel combustion, impacts of agricultural activity and biomass burning, and biological activity from the regional terrestrial ecosystems [1-5].

Most ice core drilling sites on the QTP glacier are above $6000 \mathrm{~m}$, which reached to the upper-troposphere. At such elevation, the influence of local mountain climate and environment is very less, and the ice core records can reflect a large scale condition of atmospheric environment. In this paper, we focus on a 92-year record of major ion variability in the Chongce ice core drilled from $6530 \mathrm{~m}$ elevation, West Kunlun Mountain. The ions of $\mathrm{SO}_{4}{ }^{2-}$ and $\mathrm{Cl}^{-}$in Chongce ice core were discussed before [6]. In this paper, the composition, source, influencing factors and the environmental change of the major anions $\left(\mathrm{NO}_{3}{ }^{-}, \mathrm{SO}_{4}{ }^{2-}, \mathrm{Cl}^{-}\right)$and cations $\left(\mathrm{Ca}^{2+}, \mathrm{Mg}^{2+}, \mathrm{K}^{+}, \mathrm{Na}^{+}\right)$will be discussed. 


\section{Study area and Method}

Chongce Ice Cap $\left(35^{\circ} 14^{\prime} \mathrm{N}, 81^{\circ} 07^{\prime} \mathrm{E}\right)$ is located on the south slope of the middle West Kunlun Mountains, north margin of Qinghai-Tibetan Plateau, adjacent to the Taklimakan Desert at north (Fig.1). It belongs to the Guozhacuo river basin, $138.5 \mathrm{~km}^{2}$ large, upper limited elevation of glacier is at $6846 \mathrm{~m}$, the elevation of the terminus is about $5800 \mathrm{~m}$ and the equilibrium line is at $5930 \mathrm{~m}$. The terrain conditions are propitious to glacier development.

Major anions $\left(\mathrm{NO}_{3}^{-}, \mathrm{SO}_{4}^{2-}, \mathrm{Cl}^{-}\right)$and cations $\left(\mathrm{Ca}^{2+}, \mathrm{Mg}^{2+}, \mathrm{K}^{+}, \mathrm{Na}^{+}\right)$were analyzed with a Dionex-100 ion chromatograph, and a Seiko SAS 7500 atomic absorption spectrophotometer equipped with a flame atomizer, respectively. Measurement of $\mathrm{pH}$ was done with a TOA FAR-101 pH meter. Micro-particle analysis was carried out with a Coulter Counter Multisizer, which detects number of micro-particles in a size range covered by 32 channels. The analysis of the isotopic ratio $\delta^{18} \mathrm{O}$ was carried out by an isotope-ratio mass spectrometer (Finnigan MAT).The micro-particle variation was used to date the core, and the details of dating work could be found from Han et al. [7].

\section{Results and discussions}

\section{Major ions composition}

The content of $\mathrm{Ca}^{2+}$ takes an absolutely advantage in the cations in Chongce ice core, the ionic abundance of the Chongce ice core follows the sequence of $\mathrm{Ca}^{2+}>\mathrm{SO}_{4}{ }^{2-}>\mathrm{Cl}^{-}>\mathrm{NO}_{3}{ }^{-}>\mathrm{Na}^{+}>\mathrm{Mg}^{2+}>\mathrm{K}^{+}$. These characteristics are accord with the general characteristics of the ice cores from the ice caps of inland glacier (e.g. the sources of ions are terrestrial). The ratio of total anions to total cations ( $\Sigma$ anions/ $\Sigma$ cations) in this study is 0.60 , suggesting at least one major anion was neglected. According to the inland glacier characteristic, the neglected anion is most likely $\mathrm{HCO}^{3-} / \mathrm{CO}^{2-}$.

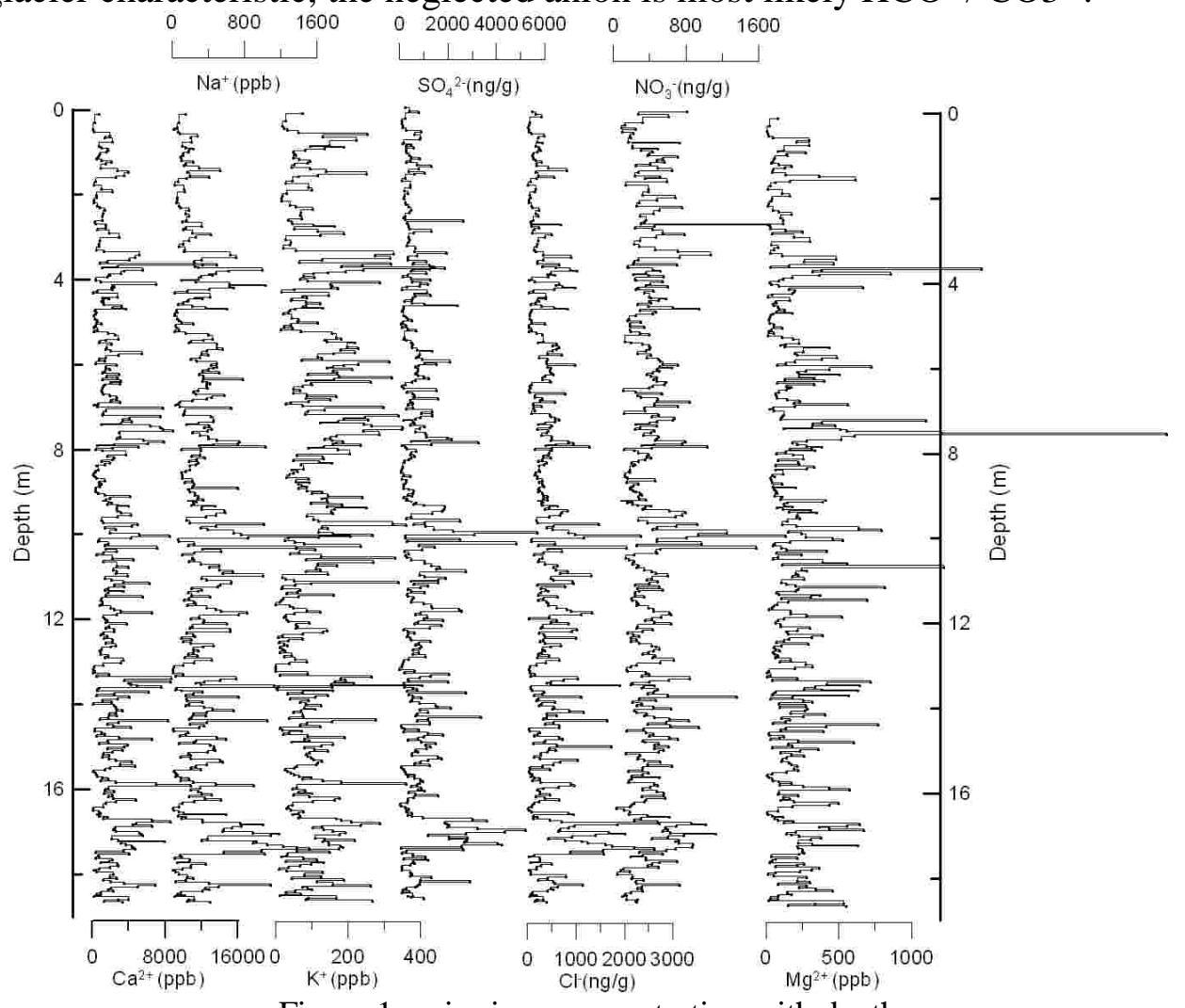

Figure 1 major ions concentration with depth

Compared with the other ice cores on QTP (table 1), the ion concentrations of Chongce ice core are similar with Guliya ice core, the nearest ice core in west Kunlun Mountain, and great discrepancy with the other ice cores. It shows that major ion concentrations in different ice cores have significant 
differences with different geographic regions, and this can be attributed to differences in source and strength of atmospheric aerosol inputs.

Table 1 Chemical elements in Chongce ice core and other short ice cores on QTP $(\mathrm{mg} / \mathrm{L})$

\begin{tabular}{lcccccccc}
\hline \multicolumn{1}{c}{ Ice core } & $\mathrm{Ca}^{2+}$ & $\mathrm{Na}^{+}$ & $\mathrm{Mg}^{2+}$ & $\mathrm{K}^{+}$ & $\mathrm{SO}_{4}{ }^{2-}$ & $\mathrm{Cl}^{-}$ & $\mathrm{NO}_{3}{ }^{-}$ & $\mathrm{pH}$ \\
\hline Guliya, west Kunlun [12] & 2.25 & 0.5 & 0.2 & 0.2 & 0.64 & 0.43 & 0.21 & $6.6 \sim 9.4$ \\
Chongce, west Kunlun (This work) & 2.17 & 0.33 & 0.21 & 0.1 & 0.82 & 0.43 & 0.41 & $5.0 \sim 8.3$ \\
Tanggula, central Tibetan Plateau [5] & 21.4 & 2.8 & 2.6 & 0.3 & 2.9 & 1.8 & 1.8 & \\
East Rongbuk, Himalayas [3] & 5.3 & 0.5 & 0.4 & 0.2 & 1.9 & 0.5 & 0.7 & \\
\hline
\end{tabular}

\section{Associated major ion sources}

The dust flux in Chongce ice core related with all ions except for $\mathrm{NO}_{3}{ }^{-}$. The most correlation coefficients between the different cations, anions are higher than 0.5 , especially $\mathrm{Ca}^{2+}$ show significant correlation with $\mathrm{Na}^{+}, \mathrm{Mg}^{2+}, \mathrm{K}^{+}, \mathrm{SO}_{4}{ }^{2-}$ and $\mathrm{Cl}^{-}$, It shows that these ions have the common resource, i.e. terrestrial crust dust. The high concentration $\mathrm{SO}_{4}{ }^{2-}$ and $\mathrm{Ca}^{2+}$ are consistent with the observed aerosols above Taklimakan desert, which characterized of high mass concentration, high content of sulfur and calcium [8]. Furthermore, the dust flux in Chongce ice core related with $\mathrm{SO}_{4}{ }^{2-}$ and $\mathrm{Ca}^{2+}$ (table 2). The coefficient between snow accumulation rate and dust flux is reached to 0.42 (table 2). Considering the Chongce ice core manifest as a "clean" ice core without any visible dust layers, indicating less noise from local dust input was introduced. And the coherent decrease of snow accumulation rate and dust deposition shows that the mineral dust in Chongce ice core contributes much to the ions as the wet deposition pattern $[9,10]$. Consistent variation tendency between dust flux in Chongce ice core and sandstorm days around Taklimakan Desert indicate the mineral dust ions are likely from Taklimkan Desert [10].

The correlation coefficients between $\mathrm{Cl}^{-}$and $\mathrm{Na}^{+}, \mathrm{Cl}^{-}$and $\mathrm{SO}_{4}{ }^{2-}, \mathrm{Na}^{+}$and $\mathrm{SO}_{4}{ }^{2-}$ are higher than 0.8 , it seems that these ions originate from the sea-salt. Actually, the major provenance of sands in the Taklimankan Desert is the Miocence paleo-ocean, and the marine sandy deposits within the ocean [11]. The other ice core studies in the northern regions of QTP reported that $\mathrm{Na}^{+}$and $\mathrm{Cl}^{-}$signals could relate to the dust derived from the arid and semi-arid regions of China $[12,13]$. Thus, sea-salt contributions to ions in the Chongce ice core are negligible.

Above all, the Chongce ice core chemistry can be characterized by ions originating mainly from mineral dust particles of Taklimakan Desert.

Table 2 Correlation coefficients between major ion concentrations in the Chongce ice core, calculated from the annual averages $(\mathrm{n}=92)$.

\begin{tabular}{|c|c|c|c|c|c|c|c|c|c|}
\hline & $\mathrm{Cl}^{-}$ & $\mathrm{NO}_{3}^{-}$ & $\mathrm{SO}_{4}{ }^{2-}$ & $\mathrm{Na}^{+}$ & $\mathrm{K}^{+}$ & $\mathrm{Mg}^{2+}$ & $\mathrm{Ca}^{2+}$ & dust flux & $\begin{array}{l}\text { accumulation } \\
\text { rate }\end{array}$ \\
\hline $\mathrm{Cl}^{-}$ & 1.00 & & & & & & & & \\
\hline $\mathrm{NO}_{3}^{-}$ & 0.58 & 1.00 & & & & & & & \\
\hline $\mathrm{SO}_{4}{ }^{2-}$ & 0.90 & 0.76 & 1.00 & & & & & & \\
\hline $\mathrm{Na}^{+}$ & 0.92 & 0.62 & 0.86 & 1.00 & & & & & \\
\hline $\mathrm{K}^{+}$ & 0.42 & 0.28 & 0.35 & 0.57 & 1.00 & & & & \\
\hline $\mathrm{Mg}^{2+}$ & 0.34 & 0.23 & 0.36 & 0.47 & 0.78 & 1.00 & & & \\
\hline $\mathrm{Ca}^{2+}$ & 0.63 & 0.41 & 0.59 & 0.68 & 0.71 & 0.79 & 1.00 & & \\
\hline dust flux & 0.17 & -0.06 & 0.40 & 0.18 & 0.23 & 0.22 & 0.32 & 1.00 & \\
\hline $\begin{array}{l}\text { accumulat } \\
\text { ion rate }\end{array}$ & 0.09 & 0 & 0.13 & 0.08 & -0.06 & 0.01 & 0.09 & 0.42 & 1.00 \\
\hline
\end{tabular}

\section{Ions concentration trends}

Trends in ion concentrations, during the period 1903-1992 were examined based on the annual averages. 


\section{Mineral dust}

Concentrations of the $\mathrm{Na}^{+}, \mathrm{Cl}^{-}$and $\mathrm{SO}_{4}{ }^{2-}$ show a similar variation in trends for the period covered by the ice core (Figure 3b, $d$ and e ) as well as high correlation coefficient between them (Table 2). During 1903-1992, the most notable peaks occurred from 1915 to 1920. After this period, the average concentration of the $\mathrm{Na}^{+}, \mathrm{Cl}^{-}$and $\mathrm{SO}_{4}{ }^{2-}$ decreased at a relatively low level. Concentrations of the $\mathrm{Ca}^{2+}$ and $\mathrm{Mg}^{2+}$ also show a similar decreased trend (Figure $3 \mathrm{a}$ and $\mathrm{c}$ ) as well as the high correlation coefficient (Table 2). But the most notable peaks occurred not during 1910s, but at the early1960s. Except for Taklimkan Desert, there exist other origins for the $\mathrm{Ca}^{2+}$ and $\mathrm{Mg}^{2+} \cdot \mathrm{Ca}^{2+}$ and $\mathrm{Mg} 2+$ are the major cations of inland glaciers, partly origin from proximal environment, i.e. Tibetan Plateau itself. In general, compared with the data of sand storm in 344 observatories in northern China (1954 2005) [14], they show a common trend: decreased since 1950s while increased in 1960s, and lessened from the 1970 s to the 1990 s.

Compared with the isotopic ratio $\delta^{18} \mathrm{O}$, accumulation rate and dust flux, the major mineral dust ions trends are basically consistent with the dust flux and accumulation rate (Figure $3 \mathrm{~g}$ and $\mathrm{h}$ ), and opposite to the $\delta^{18} \mathrm{O}$. The increased $\delta^{18} \mathrm{O}$ means the increment of glacier temperature and melt water, the increment of river runoff results in the increment of vegetation area, efficiently hinder the sandstorm occurring and reduce the mineral dust transport to the glaciers. Combined with relation between accumulation rates, dust flux and sandstorms in Taklimakan Desert [9, 10], these tiny mineral dusts play the role of condensation nuclei, the majority ions are from Taklimakan Desert and mainly deposited as the pattern of wet deposition.
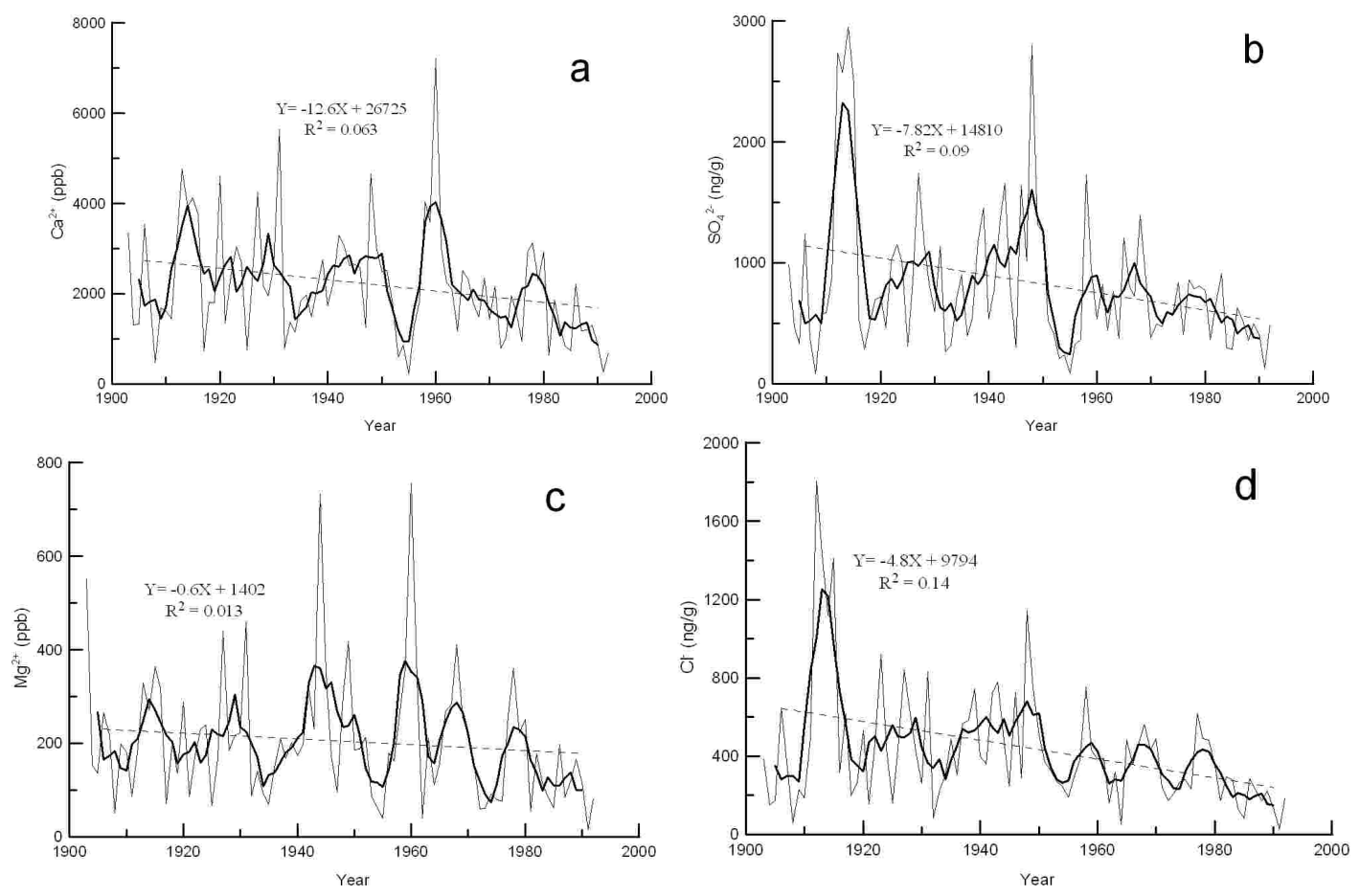

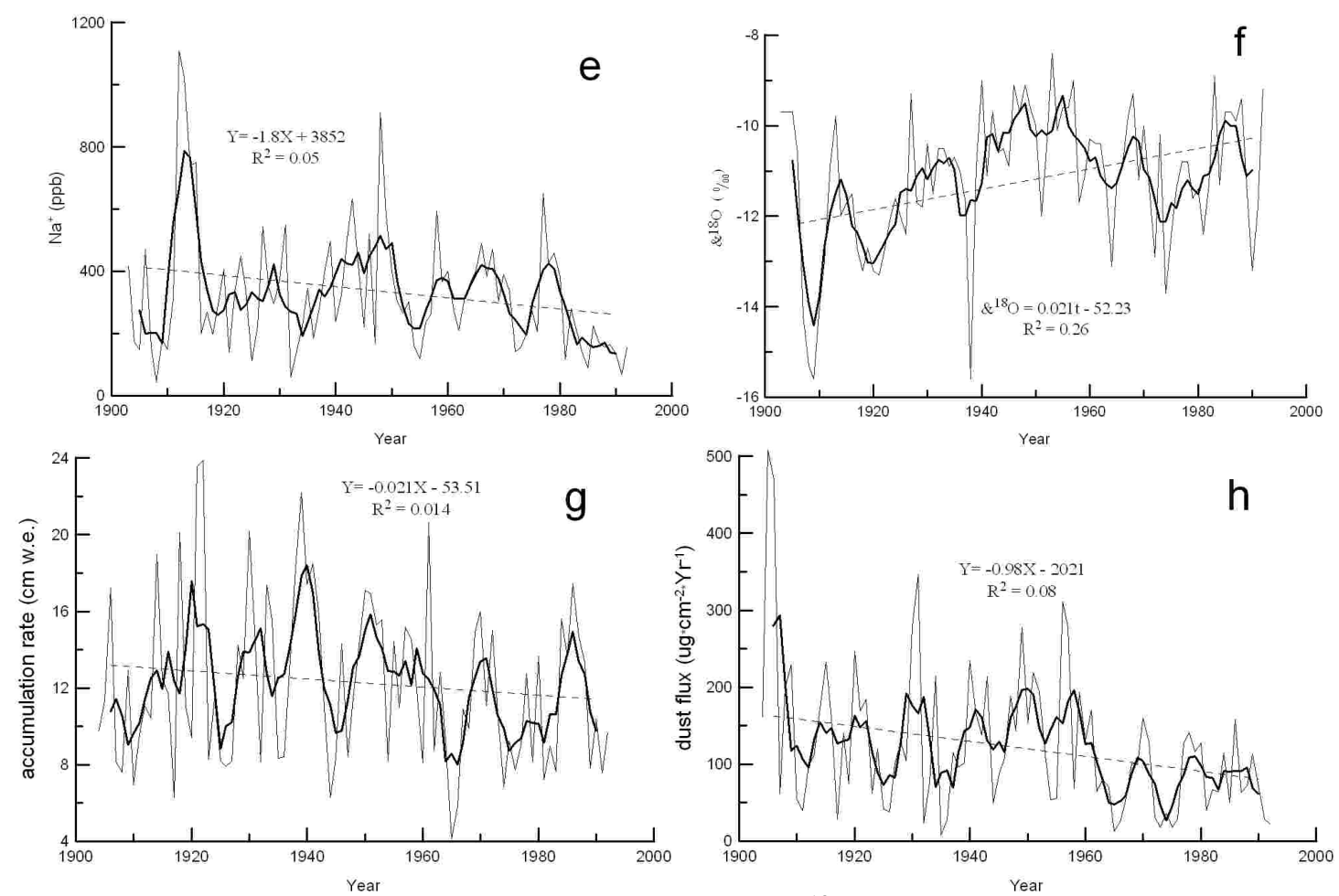

Figure 3 Variations in different mineral dusts, accumulation rate, $\delta^{18} \mathrm{O}$ and dust flux recorded in the Chongce ice core during the last century.

\section{Potassium}

As well as their high correlation coefficient (Table 2), the concentrations of the $\mathrm{Ca}^{2+}, \mathrm{Mg}^{2+}$ and $\mathrm{K}^{+}$ show a similar variation characteristic, especially from 1900s to 1950s (Figure 3a, c and figure 4), experienced the common decreased period of early 1900s to middle 1930s, and the rise period of middle 1930s to late 1950s. Their most notable peaks occurred at early 1960s. After 1950s, although their variation curves are similar, the increased amplitude of $\mathrm{K}^{+}$is much higher than $\mathrm{Ca}^{2+} \mathrm{and}_{\mathrm{Mg}^{2+}}$. This results that $\mathrm{K}^{+}$show an increased trends, different to the other mineral dust ions (Figure 4). In other words, there is another potassium inputs except for the mineral dust after 1950s.

For the north Tibetan Plateau far away from seas, the biomass burning is an important source of potassium (the portion not attributable to soil dust). For the people lived in Taklimakan Desert, vegetation is their main fuel source for a long time. With vegetation burning, a lot of fine potassium aerosol was emitted to the atmosphere [15]. From the beginning of 1950s to the early 1980s, the population of Tarimu basin increased from 2 to 7 million. Population growth led to the increase in fuel demand and more vegetation burning [16]. Probably, that is why potassium increased after 1950s.

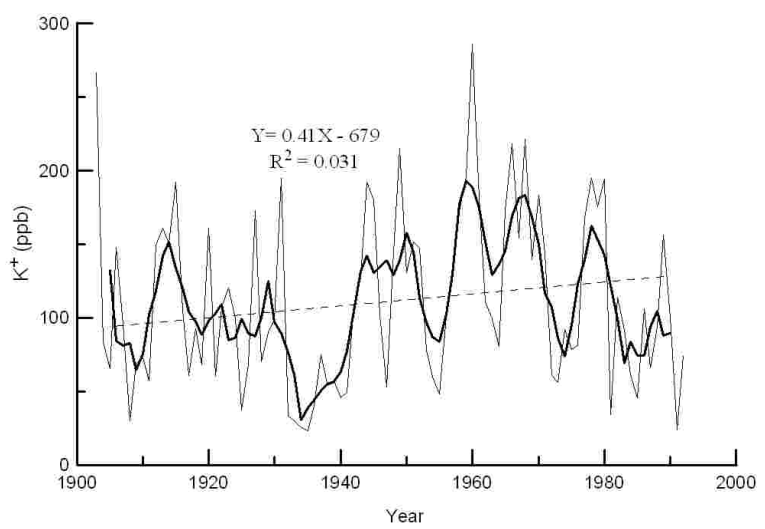

Figure 4 Variations in potassium recorded in the Chongce ice core during the last century. 


\section{Nitrate}

Different to the other ions above, $\mathrm{NO}_{3}{ }^{-}$keep a relatively stable variations during the last century. There is no obvious increasing and decreasing trend, although the fluctuation amplitude is high. It is difficult to confirm what environmental information $\mathrm{NO}_{3}{ }^{-}$indicates in Chongce ice core. The source of $\mathrm{NO}_{3}{ }^{-}$is very complex, related with volcano eruption, fossil burning, biomass burning, soil microbial activity, dust mineral, solar irradiation and lightning. Ice core studies at the periphery of the QTP have shown that over the past half-century, high concentrations of $\mathrm{SO}_{4}{ }^{2-}$ and $\mathrm{NO}_{3}{ }^{-}$were mainly due to increasing anthropogenic emissions $[3,5]$. But in Chongce ice core, the concentrations of $\mathrm{SO}_{4}{ }^{2-}$ show a decreased trend during last century, this means the contribution of fossil burning to the concentration of $\mathrm{NO}_{3}{ }^{-}$is very little. Considering the special geographic position of Chongce ice cap, locating at northwest QTP, Taklimkan Desert in north, Pamir Plateau in west, vast QTP in south and Qaidam Basin in east, the soil microbic activity is very week in such extreme environments. And the contribution of soil microbic activity can be neglected. The correlative coefficient between dust flux and $\mathrm{NO}_{3}{ }^{-}$is roughly 0 , this proved $\mathrm{NO}_{3}{ }^{-}$is not from dust flux and uncorrelated with sandstorm transport. So, the source of $\mathrm{NO}_{3}{ }^{-}$is probably related with solar irradiation and lightning. Through the power spectrum analysis, there exists an obvious period of 11-17 years (Figure 6). It is worth to study deeply whether the variation of nitrate ions effectively represents the solar irradiation variation.

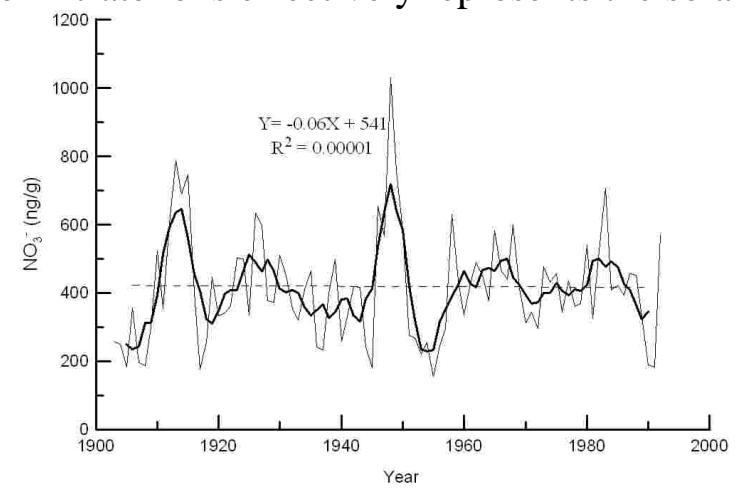

Figure 5 Variations in nitrate ion recorded in the Chongce ice core during the last century

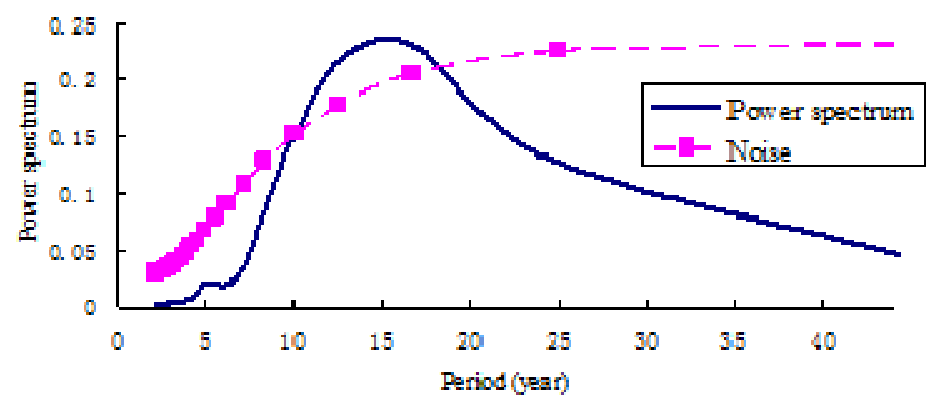

Figure 6 Power spectrum analyses of nitrate ion records

\section{Conclusion}

In this study, the Chongce ice core provides a detailed glacialchemical record of different soluble ions. Based on the composition and concentration of different ions in Chongce ice core, comparisons with the dust flux, accumulation rate and $\delta^{18} \mathrm{O}$ in Chongce ice core, the major ions are mainly originated from Taklimkan Desert through sandstorm transport and wet deposition process. The major mineral dust ions $\mathrm{Ca}^{2+}, \mathrm{SO}_{4}{ }^{2-}, \mathrm{Cl}^{-}, \mathrm{Na}^{+}$and $\mathrm{Mg}^{2+}$ show a decreased trend during the last century, in according with the decreased sandstorm frequency occurring in Taklimkan Desert. The potassium ions show an increased trend during last century, especially after 1950, this probably related with the increased biomass burning. The nitrite ions show a relatively stable variation during the last century, 
and exist an 11-17 years period. The relationship between irradiation and nitrate ions variation is worth to study deeply in future work.

\section{Acknowledgements:}

Supported by the Guide Fund for Youth of Qinghai Institute of Salt Lakes, Chinese Academy of Sciences, platform 271 Construction for Key Laboratory in Qinghai Province (grants 2013-Z-Y12) and Natural Science Funds of Qinghai Province (2011-Z-926Q).

\section{References}

[1]. Yao T., Wu G., Pu J., Jiao K. and Huang C. Relationship between calcium and atmospheric dust recorded in Guliya ice core. Chinese Science Bulletin. 49 (7), (2004) 706-710.

[2]. Kang S., Dahe Q., Mayewski P. A. and Wake C. P. Recent 180 Year Oxalate (C2O42-) Records Recovered from the Mount Everest Ice Core: Some Environmental Implications 1-1 (2001) 154-156.

[3]. Kang S., Mayewski P. A., Qin D., Yan Y., Zhang D., Hou S. and Ren, J. Twentieth century increase of atmospheric ammonia recorded in Mount Everest ice core. Journal of Geophysical Research: Atmospheres (1984-2012), 107 (D21), (2002) ACL-13.

[4]. Duan K., Thompson L. G., Yao T., Davis M. E. and Mosley - Thompson E. A 1000 year history of atmospheric sulfate concentrations in southern Asia as recorded by a Himalayan ice core. Geophysical Research Letters. 34, 1 (2007) 325-345.

[5]. Zheng W., Yao T., Joswiak D. R., Xu B., Wang N. and Zhao, H. Major ions composition records from a shallow ice core on Mt. Tanggula in the central Qinghai-Tibetan Plateau. Atmospheric Research. 97, 1 (2010) 70-79.

[6]. Liu Y., Liu Y. and Han J. Chlorine ion and sulfate ion records in Chongce ice core. Yunnan geographic environment research. 19, 3 (2007) 35-38 (Chinese version with English abstract).

[7]. Han J. Dating of a Shallow Ice Core from Chongce Ice Cap using micro-particle content. (Chinese version with English abstract)Journal of Glaciology and Geocryology. 27, 6 (2005) 847-852.

[8]. Wang X., Xia D., Wang T., Xue X. and Li J. Dust sources in arid and semiarid China and southern Mongolia: Impacts of geomorphological setting and surface materials. Geomorphology. 97, 3 (2008) 583-600.

[9]. Han J., Nakawo M., Goto-Azuma K. and Lu C. Impact of fine-dust air burden on the mass balance of a high mountain glacier: a case study of the Chongce ice cap, west Kunlun Shan, China. Annals of Glaciology. 43, 1 (2006) 23-28.

[10]. Chongyi E., Yong W., Taibao Y., Jiankang H., Hongchang H. and Fengmei Y. Different responses of different altitudes surrounding Taklimankan Desert to global climate change. Environmental geology. 56, 7 (2009) 1281-1293.

[11]. Sun J. and Liu T. The age of the Taklimakan Desert. Science, 312(5780), 1621-1621 (2006).

[12]. Li Y., Yao T., Sheng W., Huang C. and Xie C. A Geochemical Study on an $8 \mathrm{~m}$ Depth Ice Core of Guliya Ice Cap. (Chinese version with English abstract).Journal of Glaciology and geocryology.19, 2 (1997)173-179.

[13]. Wake C. P., Mayewski P. A., Zichu X., Ping W. and Zhongqin L. Regional distribution of monsoon and desert dust signals recorded in Asian glaciers. Geophysical Research Letters. 20, 14 (1993) 1411-1414..

[14]. Ding K and Liu J.P. Spatial distribution dynamic changes of sand storm in northern China in recent 50 years. (Chinese version with English abstract) Journal of Arid Land Resources and Environment. 4 (2011) 81-93. 
[15]. Andreae M. O. Soot carbon and excess fine potassium: Long-range transport of combustion-derived aerosols. Science. 220, 4602 (1983)1148-1151.

[16]. Tursun K., Ayixianmu S., Zumulati Y. and Zumulati M. The human-driven reasons of desertification on the lower reaches of Tarim River (Chinese version with English abstract) Journal of Arid Land Resources and Environment. 26, 4 (2012) 18-23. 